\title{
An Empirical Study of Effective Teaching in Kindergarten Health Field
}

\author{
ZHANG Xi-zhen \\ Zaozhuang University
}

\begin{abstract}
As the first curriculum of the five major areas of kindergarten, health field plays an important role in the healthy growth and development of children, whose important role mainly depends on the implementation of courses and the effective teaching in health field. On the basis of sampling survey, this paper analyzes the current situation of effective teaching in the field of kindergarten health, and puts forward some suggestions such as strengthening theoretical study and establishing correct mental health education view, carrying out education teaching activities in various forms in health field; strengthening the connection between kindergarten and family and making the family work in the healthy education of children; Moreover, appropriate education method and various education forms were adopted to implement healthy education teaching activities and get the work of education in children's mental health well done.
\end{abstract}

Keywords-Health; Healthy education; Effective teaching; Empirical research

\section{INTRODUCTION}

In July 2001, the ministry of education to carry out the education law of the People's Republic of China, the kindergarten management ordinance and the kindergarten work regulation, guide the kindergarten into quality education, formulated the "kindergarten education guidelines (try out)", made clear: kindergarten education content is comprehensive, enlightening, relatively divided into health, language, society, science, art, and other areas of the five permeable. The discussion of health field puts forward emphatically: "kindergartens must put the protection of children's life and the promotion of children's health education in the first place." And set the goal of the health field as "physical health, emotional stability and happiness in the collective life; Good habits and basic self-care ability; Know the necessary safety knowledge and learn to protect yourself. Like to participate in sports activities, action coordination, flexibility. From this a series of statements, it can be seen in the importance of children's physical and mental development and health field, the importance can be play, play to what extent, largely dependent on the implementation of the health curriculum, that is to say, effective teaching in the field of health to a great extent, affects the healthy development of young children. The kindergarten education teaching practice in our country, as the first of the five areas of health curriculum implementation present situation how, whether to preschool education programmatic documents related to the guidelines specified in its goal, are all engaged in preschool education theory and practice workers must be worthy of attention. We are clearly aware that the actual effect of education in kindergarten health cannot be separated from the effective implementation and development of teaching activities in health field. Based on this, this paper used the methods such as observation method and interview method, the current our country kindergartens health information on the development of the implementation of the teaching activities and has carried on the investigation, in order to obtain relevant results are beneficial to the nursery school health education.

In September 2012, the ministry of education of the 3-6 years old children's learning and development guide ", made a clear definition of the meaning of the health: health refers to people in the physical, psychological and social adaptation in good condition. Early childhood is a period of rapid physical development and functional development of children, and it is also an important stage of developing a sense of security and optimistic attitude. Well developed body, happy mood, strong physique, coordinated action and good living habits and basic life ability is an important symbol of children's physical and mental health, is also the basis of learning and development in other fields. Educators at home and abroad have made detailed discussions on the importance of sports in the development of children or the important role of physical health in the development of human life.

\section{EDUCATIONALISTS AT HOME AND ABROAD ON THE IMPORTANCE OF PHYSICAL HEALTH OR SPORTS}

Famous British educator John Locke, the first time in the history of education into three parts of moral, intellectual, physical education content, first put forward and a detailed discussion on children's physical problems, fully affirmed the importance of children's sports. The first sentence in his representative work education is "healthy spirit in healthy body". Locke, as the representative of the gentleman education think a gentleman will make their own career success, to achieve the happiness of the individual, there must be a strong physique as the foundation, and special emphasis on physical exercise to cultivate the will of a gentleman, especially the spirit of "patient toil".

French educator is the representative figure of Rousseau's natural education thought, and puts forward the idea of education must conform to nature, think that education should pay attention to the age characteristics of children, at different times for different education. He suggests that in infancy, mainly for sports, main task is to promote the health of the 
children's physical development, because health is the foundation of wisdom, is the children accept the condition of natural education, points out that to exercise the physique of children, let children to endure severe season, climate and weather, able to endure hunger and fatigue.

Yan yuan, the educationist of the qing dynasty, said, "you should not be good at learning and moving. The meaning of this sentence is: to maintain the body is the best way to get into the habit of love sports, sport, however, a person is strong, the family sports is strong, the whole family national sport, however, the people is strong, movement when a strong one. Is known as "the first person of Chinese Olympic" famous educator chang po-ling, once said: "there's no sports in education, education is not complete", "strong I race, sports first", fully embodies the thought of he attaches great importance to physical education. Our country the famous children's educators Chen Heqin in the $1920 \mathrm{~s}$, it puts forward the idea of "five fingers activities", the kindergarten curriculum content is divided into health, social activities, five items of scientific activities, art activities, and to emphasize the five kinds of activities as a whole, as a man's finger and palm, fingers is only part of the palm of your hand, connected to the same flesh and blood, the blood is same.

Comrade MAO zedong attached great importance to sports and discussed the importance of sports many times in his works. As early as April 1917 published by the "research of sports" wrote: "a body, with the moral education and intellectual education, and wisdom are sent in body, no body is without virtue", dialectically discusses the physical education and moral education, intellectual education, each other, be short of one cannot close contact; Paper also mentioned "body, load the car and the house of the combine moral" of knowledge, lively and vividly illustrates the importance of sports, compared the body to "take the car of knowledge", "moral of homes", the car firm, will be much faster; Only when the house is not broken can we live in peace, be physically strong, be energetic and have a pleasant mood to study, work and live. A strong body is the material basis of moral and intellectual education. After the founding of new China, he emphasized many times this problem, proposed in 1951 to "health first, learning a second", in 1952 wrote "the development of sports, improve the people's physical fitness" the inscription, as the national people's sports work policy, in 1953 to the national youth issued a "keep fit, study well, work well" great call.

\section{ANALYSIS ON THE CURRENT SITUATION OF EFFECTIVE TEACHING IN THE FIELD OF KINDERGARTEN HEALTH}

The idea of effective teaching originated from the scientific movement of teaching in the first half of the 20th century. The so-called effective, is mainly refers to by the teacher after a period of teaching, students gained by the progress of body and mind, its core is the efficiency of teaching, that is, what kind of teaching is effective, students have any progress or development is the only indicators of effective teaching. Effectiveness includes three meanings: effective, efficient and effective.

Kindergarten effective teaching means teachers according to the needs of young children's physical and mental development rule, interests, and follow the rule and principle of preschool teaching activities, with the least amount of time and money, the lowest price, in the teaching content, for mediation, to maximize the teaching effect, the greatest degree of play to promote early childhood development function of teaching activities

In order to accurately grasp the present situation of the current our country health kindergarten teaching activities, the author selected several local kindergarten as the research sample, sampling observation method, interview method and other methods for investigation, to collect relevant material to carry on the detailed analysis, get the following conclusion.

\section{A. Current achievements in effective teaching in the field of kindergarten health}

Kindergarten leaders and teachers can basically grasp the kindergarten education guidelines (try out) "and" the 3-6 years old children's learning and development guide "and other relevant documents spirit, in kindergarten education teaching work, can according to the age characteristics of children, from the form can be well on the relevant health teaching activity, the contents of health education teaching activities are rich and colorful, to a certain extent, to inspire the interest of children to participate in the activities of health, improve the enthusiasm and initiative of children to participate in healthy activities.

In the teaching practice of education in kindergarten, I can pay more attention to children's physical health, pay attention to children's nutrition and diet, and make reasonable catering, so as to ensure the normal growth and development of children's body. Can at the same time, in the form of different activities to carry out activities in the field of health, can be in accordance with the provisions of the kindergarten work procedures to carry out outdoor activities, not less than 1 hour per day, some of the kindergarten has broad sports, outdoor sports equipment, can adapt to the children dispersed group or individual activities, can be fully considered and both young children's different interest, hobby and ability level.

In the field of health education teaching activities in kindergarten, most kindergarten can establish colorful environment for the children, teachers can choose according to the goal of health education theme, make full use of the daily life of the natural environment, guide children to practical things in life, people's behavior and attitude to see the real, physical observation and observe the truth, cause children's perception of things, behavior, arouse the desire of the children's learning, pay attention to the introduction and explanation of related health knowledge.

Nursery school health education teaching can embody in all areas of mutual permeability, pay attention to children's thinking ability, cooperation consciousness, the cultivation of the brave quality, through the health education teaching shows "play school", "high school" education consciousness, do well in all areas of mutual penetration, young children in a pleasant mood to complete the training of the thinking, at the same time cultivate children good non-intelligence factors. Education is available for children's health problems at any time through outdoor activities, formal activities and daily life activities. 
Investigation by most of the kindergarten, in the field of health education teaching activity, has made some achievements and experience, but still with some problems and weaknesses of different level, to the kindergarten education theory and practice workers rationally and correctly face.

\section{B. The deficiency of effective teaching in the field of kindergarten health}

Nursery school health education in the field of teaching, the part of the kindergarten teachers and the understanding of the meaning of health is not comprehensive, the concept of health and health education contents, limited to physical health, stay on the concept of personal health. One is to equate health education with health care and exercise. Teachers only pay attention to children's health education in health care and sports activities. When carrying out health education to children, they only teach children health, sports education and other aspects of knowledge and skills. Second, children's mental health problems do not attract enough attention from teachers, who believe that children are too young to cause psychological problems and ignore children's personality cultivation and happy experience. A research institution on a region of 50004 6 years old children's psychological health condition investigation results show that the current children's mental health is not optimistic, $9.7 \%$ of children had bad behavior, $14 \%$ of the preschool depressed, self-abased, $8.9 \%$ of the children's anxiety, tension, etc. There are some unhealthy phenomena in children, such as selfishness, bad temper and strong aggression. However, when implementing healthy education teaching activities in kindergartens, education in mental health is often ignored and ignored to a large extent.

Some kindergarten lack of sports facilities and equipment, lack of the corresponding activity space, lead to kindergarten sports activities to carry out accordingly, organization activity, unreasonable on the sports materials, equipment couldn't reflect the administrative levels sense, young children cannot choose content, cannot satisfy the children's individual differences to the needs of the health and sports.

Kindergartens lack corresponding physical education teachers. Some teachers to introduce and explain the health knowledge, but in some related physical activity, often lack the corresponding sports skills, activity for young children can't be sure, for some sports action cannot correct demonstration, unable to guarantee the quality of sports activities.

Now due to schools of various levels are very pay attention to safety education, to evaluate the quality of the education of kindergarten indicators "one ticket is overruled make safety", under the reality of the situation, some kindergartens to "safe" for the purpose of, and narrowed the scope of children in the garden, or even cancelled some outdoor activities and sports activities, the children all day "off" in the classroom, to a large extent affected the children's normal development and health.

\section{STRATEGIES FOR EFFECTIVE TEACHING IN THE FIELD OF KINDERGARTEN HEALTH}

Strengthen theoretical study, set up the correct mental health education, clear the importance of children's health, from the ideological concept, change the kindergarten a line workers understanding and the understanding of the meaning of health, strengthen the management of kindergartens health activities, inspire teachers to further improve and adjust the motivation and behavior of health education teaching activities, strengthen and promote the successful experience, truly make the kindergarten to the importance of health education teaching activities.

Carry out education teaching activities in various health fields, such as healthy life activities, healthy conversations, sports activities, outdoor health activities, sports activities, hiking activities, etc. The theme of the activities can be generated by young children spontaneously, also can be determined by the teacher, can also be produced by the teachers and students together, whether it is generated by who, to embody the children's active participation in activities and exploration, cause children's interest in the activities and guide the children to take the initiative to experience.

Have a purpose, planned and organized to carry out sports activities, give full play to the function of the children of physical education and sports, sports activities available try method, exploration method, in the game as the main activity form, stimulate interest in young children to participate in sports activities. Guarantee the outdoor activities, shall not be less than 1 hour per day, let the children the freedom to choose sports and sports equipment, free game together, young children and the ability to choose according to their own interests, activities, optional activities to develop their own action and physical quality, which can be relaxed, happy, free activities.

Play to the role of the hiking activity, and the physical and mental development rule based on the characteristics of young children's age, according to the principle of gradual, design way and regulation speed, determine the activity, the organization to be flexible and varied in form, arrange the content is rich and colorful, make children is keen interest in the process of hiking activity, must put safety first, method of teaching young children learn to protect themselves.

Strengthen the connection between kindergarten and family and play the role of family in the healthy education of children. "Education in schools with no family education and education in families without education are not able to complete the extremely small task of cultivating people," suhomlinsky once said. In the process of the development of young children, kindergarten education and family education plays an important role to the health of children, the two complement each other and restraining each other, but the reality is that the two from each other in the children's health education. Parents believe that as long as children to kindergartens, all education is the responsibility of teachers. As two main institutions of education, kindergartens and families play different roles. Only when the two are combined and interact with each other can education be given full play to children's health and promote their healthy growth. Parents are an important factor that 
cannot be ignored in the education of children's health. If any activity can be carried out with the support and cooperation of parents, it will often get twice the result with half the effort.

Mr. Chen heqin once said, "Children cannot live without life, and life cannot live without health education. Children's life is rich and colorful. Proper education method and various education forms were adopted to implement healthy education teaching activities. For example, practical operation method, perceptual experience method, game method, situational performance method, etc., through relaxed and happy games, children do not know whether they have improved their skills and formed habits. Healthy education was infiltrated into children's daily life and integrated into education activities in various fields. Collective health behavior guidance is combined with individual health behavior guidance, health education and environment education. For example: through outdoor equipment to carry out the rich sports activities, using the kindergarten environmental health education of young children, combined with the activities in the kindergarten, organize children to develop good care environment and health, protecting the environment and health, maintain environmental health education, to cultivate children have good health, good care environment of behavior, create let children take the initiative to participate in physical exercise of the external environment, stimulate children's interest in physical exercise.

\section{EduCATION Work ON ChILdREn's Mental HeAlth}

Teachers should create a relaxed, democratic and positive education environment for children, so that children can keep a relaxed and happy mood, so that children's psychology can be developed healthily.

Make clear the meaning of children's mental health, grasp their behavioral motivation, meet and guide their needs, help them to understand and evaluate themselves objectively, respect children and love them. Teacher's love for children is the most precious nutrient in education. Create a suitable for the healthy development of children's psychological environment, teachers need to pay attention to their mental health, teachers should always stay calm and pleasant mood, young children living in the relaxed happy atmosphere. We should create a natural environment full of vitality and cultivate children's mind, so that children can have more contact with nature. To provide children with a free activity of game places and some attractive toys, let the children in their own world, free games, happily guide children to establish a good peer relations, in an open environment, increase the chance of young children's exchanges, promote the formation of children's psychological health.

People often say: happiness is the source of health, only healthy is happy. In order to let every healthy happy growth of children, as young children education worker, should undertake the duty and responsibility for their own, and actively explore and forge ahead, in view of the current kindergarten health education teaching activities in the field of the status quo, research and practice of effective teaching, through the health education in the field of teaching, make our education objects, children become healthy, can accept the challenge and adapt to the future society needs a new generation.

\section{CONCLUSION}

Through the above analysis and demonstration, our research has reached the following conclusions: in order to strengthen the effective teaching in the field of kindergarten health, it is necessary to change the understanding and understanding of health meaning of front-line workers in kindergartens from the perspective of ideology, and strengthen the management of health activities in kindergartens. Games as the main form of activity; strengthen the connection between kindergarten and family and play the role of family in the healthy education of children; Education was infiltrated into children's daily life and integrated into education activities in various fields. Teachers should create a relaxed, democratic and positive education environment for children, so that children can keep a relaxed and happy mood, so that children's psychology can be developed healthily.

\section{REFERENCES}

[1] Cao liping, on the application of information technology in the field of kindergarten health, scientific public (science education), 2012.6.

[2] Guan chunyan, on the teaching of kindergarten health field, new course (part I), August 2014.

[3] Yang nan, comparative study on education goals in the field of infant health in China and Japan, journal of qihar normal university, July 2016.

[4] Chen wenli, the exploration and practice of this teaching and research institute in the theme park of kindergarten health field, contemporary preschool education, 2016.

[5] Research group of teacher qualification examination: teaching preservation knowledge and ability, university of electronic science and technologypress, March2013.

[6] Tian xingjiang et al., discussion on effective teaching of mathematics in kindergartens, education of modern primary and secondary schools, 5th issue, 2014. 